\title{
OBLIGATION TO SUPPORT DISABLED PERSONS IN COMPLIANCE WITH THE PRESENT INTERNATIONAL LEGAL NORMS AND OTHER INTERNATIONAL PROVISIONS
}

\author{
Ehor Nazymko', Olena Nazymko²
}

\begin{abstract}
One of the fundamental social, socio-forming institutions, which are strictly protected, including through the relevant rules of the current law, is the longstanding institute of support for persons who are unable to provide for themselves through the special disability or incapacity at all. A very important socio-institutional and socio-regulatory component of such an institution is a social consensus about the support of people with physical disabilities, which is constantly reproduced and permanently required by social communities. Among many components of the mentioned consensus, of great importance was also the indispensable obligation to carry out the full, decent or at least minimally necessary financial and material and other such support, provided by law and moral and ethical tradition, first by the parents of their young and minor children, and then, in turn, by adult, legally capable children of their older persons, including disabled, socially vulnerable parents. In spite of the necessity of careful treatment by society towards the disabled, in each country, this obligation is regulated in different ways. Therefore, it seems appropriate to analyse the obligation to keep disabled persons within the meaning of current international law and other international provisions. Methodology. The goal is solved using the cognitive potential of the system of philosophical, scientific, and special methods. The analysis and synthesis made it possible to identify the signs of incapacity for work and the specifics of the responsibilities for the maintenance of disabled persons. The methods of grammatical consideration and interpretation of legal norms have contributed to the identification of universal legal constructs that can be used in the national legislation of any sovereign country of the world. The comparative-legal method allowed determining the directions of development of national legislation of sovereign countries in order to bring them into conformity with generally accepted international standards. Practical implications. The peculiarities of the social and legal status of disabled persons require scientists to develop consistent measures of the proper legal protection of their rights. This requires establishing a clear contentspectral relationship between the concepts of such vulnerable, helpless social-group categories as "older persons", "persons with disabilities", and "mentally retarded persons", which implies a broad socio-physical contextual concept of "disabled person". The national legislation of each sovereign country should provide for a mechanism developed at the international level for collecting funds for the benefit of certain socially vulnerable persons, including the disabled.
\end{abstract}

Key words: financial support, disabled parents, aged persons, invalid persons, mentally retarded persons, present international law, subject-matter, special UN law sources, UN instruments.

JEL Classification: K14, K15, K33

\section{Introduction}

Originating from the earliest times of human history, the duty of able-bodied members of society to carry out decent or at least minimally acceptable and tolerable financial maintenance of incapacitated members of society is an extremely important humanistic normative component of modern international and national law.

Within the subject-oriented, specialized sources of the current international law and many other international instruments of a different purpose character, the fundamental social right of a number of objectively disabled persons, in particular, the aged disabled parents, to receive the necessary material, i.e. financial or any other similar support by persons defined by law is quite clearly stated and up-to-date.

The relevant rules of the current international law also clearly point to a grave social danger of action, which is the evasion or outright criminal refusal to make regular

\footnotetext{
Corresponding author:

${ }^{1}$ Donetsk Law Institute of MIA of Ukraine, Ukraine.

E-mail: nazumuch01@gmail.com

${ }^{2}$ Donetsk Law Institute of MIA of Ukraine, Ukraine.

E-mail: nazymkoov@gmail.com
} 
payments of the funds necessary for the normal life of persons who are recognized as objectively unable to earn the money they need on their own.

Direct tragic consequences of the evasion of legally identified persons from monetary and other such material support of certain categories of disabled persons may be the death of such persons due to illness, failure to receive medical treatment, suffering from hunger, etc.

The most up-to-date and important is the new, thorough, comprehensive, and detailed scientific understanding of norms of the current international law and international declarative, advisory, and moralethical provisions, which together state the duty of adult, legally capable and able-bodied children to provide financial or other similar material maintenance for their disabled parents.

Some of the issues outlined were researched by such scientists as G. Szmukler, M. Bach (Szmukler, Bach, 2015), Y. Basson (Basson, 2017), See J-F. Durieux, J. McAdam (Durieux, McAdam, 2004).

The purpose of this article, therefore, is the proper presentation, review, broad characterization, detailed analysis, and necessary scientific and research actualization of the content of both mandatory international legal norms and international declarative, advisory, and moral and ethical provisions that collectively state the obligation of adult, legally capable, and able-bodied members of society to provide financial or any other similar material maintenance of disabled persons.

The gradual and successful achievement of the stated purpose of this article has been accomplished by the proper and necessary appeal to the sources of the current UN law and other UN documents, presented in the official Ukrainian and Russian versions.

\section{Conceptualization of the obligation to support disabled persons in international legal acts}

Since the second half of the XX century, that is, since the founding of the UN, within a variety of branch sources of international law and international documents of purely declarative, advisory, orienting, moral-ethical, and other purpose character, i.e. within a number of international universal and subject-oriented, specialized conventions, declarations, principles, standard rules, and action programs, the basic social law of a number of specific categories of disabled, physically and socially vulnerable, socially helpless persons to be on regular financial or other similar material support of other persons determined by the content of the relevant norms of the national branch legislation is regularized and actualized.

Such socially vulnerable, socially helpless persons who freely use the said social law, which is extremely important to them, have been identified in the relevant sources of contemporary international law and other UN documents, in addition to minor children and parties to official marriage, the older persons, persons with disabilities, and mentally retarded persons; it is extremely important, natural, and probable that any of the categories listed above may also include elderly incapacitated parents.

First of all, it should be noted that the relevant paragraphs and articles of the Declaration on Social Progress and Development on 11 December 1969 (paragraph "c", Art. XI), (Declaration on Social Progress and Development, 1969), Declaration on the Rights of Mentally Retarded Persons on 20 December 1971 (paragraph 3) (Declaration on the Rights of Mentally Retarded Persons, 1971), and Declaration on the Rights of Disabled Persons on 9 December 1975 (paragraph 7) (Declaration on the Rights of Disabled Persons, 1975) collectively state the general social right of both mentally retarded persons and persons with disabilities to material or, in other words, socio-economic security, a satisfactory standard of living, and well-being.

The specific components of these general concepts, in particular, the concept of "a sufficient standard of living," which indicate one of the quite important aspects of the life of any person, are, for example, set out in the Universal Declaration of Human Rights as of 10 December 1948 (Art. 25) (Universal Declaration of Human Rights, 1948), International Covenant on Economic, Social and Cultural Rights as of 16 December 1966 (paragraphs 1 and 2, Art. 11) (International Covenant on Economic, Social and Cultural Rights, 1966), and Convention on the Rights of Persons with Disabilities as of 13 December 2006 (Convention on the Rights of Persons with Disabilities, 2006). Thus, the specific components of the concept of "the right of everyone to an adequate standard of living" that is "necessary to maintain health and well-being for himself and his family" are "food, clothing, housing, medical care, and necessary social services" (Universal Declaration of Human Rights), or "adequate food, clothing and housing, and to the continuous improvement of living conditions" (International Covenant on Economic, Social and Cultural Rights and Convention on the Rights of Persons with Disabilities).

Paragraph 1 of the "Independence" Section of the United Nations Principles for Older Persons on December 16, 1991, provides, in turn, not only the fundamental socio-economic right of older persons as such but also their right to legitimately receive the abovementioned vital material benefits, including money, from their relatives, family members, communities, etc. (provided from the original source): "1. Older persons should have access to adequate food, water, shelter, clothing and health care through the provision of income, family (emphasis added) and 
community support and self-help" (United Nations Principles for Older Persons, 1991).

Thus, it should be noted that, despite the fact that the right of certain categories of disabled persons, in particular, aged incapacitated parents, to be on regular financial or related support of other persons determined by the content of the relevant rules of branch national legislation is, so to speak, their specific right, the exercise of which is conditioned by the existence of certain fundamental circumstances of a social and purely physical nature, this right is clearly stipulated, in turn, by the universal, fundamental right of any person to a decent socio-economic security and a decent level of satisfaction of vital material needs without discrimination based on racial, ethnic, national, religious-confessional, sexual, and socio-property class affiliation.

\section{The interrelationship of the social-group categories of "older persons", "persons with disabilities", and "mentally retarded persons"}

Within the framework of the aforementioned sources of the current UN law and another UN documents, in our opinion, the natural and undeniable substantivespectral correlation between the above concepts of such vulnerable, helpless social-group categories as "older persons", "persons with disabilities", and "mentally retarded persons" is clear enough.

Despite the extraordinary weight, importance of a common factor of social roles, in particular, despite the sufficiently well-grounded by scholars and actualized in modern international law subjectivity and artificiality of the difference between the social roles of disabled persons and the social roles of non-disabled persons, within a purely conceptual approach, one should focus on the content and significance of certain objective factors and traits inherent in these socially vulnerable categories.

Thus, in our view, the substantive-spectral correlation between the concepts of "older persons", "persons with disabilities", and "mentally retarded persons" is sufficiently clearly and concisely stated in the Declaration on the Rights of Disabled Persons (presented from the original source): "1. The term "disabled person" means any person unable to ensure by himself or herself, wholly or partly, the necessities of a normal individual and/ or social life, as a result of deficiency, either congenital or not, in his or her physical or mental capabilities" (Declaration on the Rights of Disabled Persons, 1975).

Thus, in our view, the question arises, on the one hand, about a sufficiently broad meaningful interpretation of such concepts as "disabled person" and "mentally retarded person", and on the other, about a certain direct and indirect connection of these supposedly narrow, conventional concepts with the concept of "older incapacitated person".
Firstly, it should be noted that the concept of "a person with disabilities", as we see, meaningfully implies both a separate presence of factors of a significant lack of physical or mental abilities of a person, and their combination. Secondly, the disability, that is, in this context, a congenital or acquired defect or a limited physical and/or mental capacity of a person, is often inherent in the elderly who thus can objectively be declared incapacitated. Thirdly, the "necessities of individual life" should be understood as a wide range of regular vital human needs: food, clothing, other goods, medical services, leisure activities, etc. The problem of meeting these needs is also known to face disabled persons, in particular, aged incapacitated parents. Fourthly, the content of the very essence of the above disability concept, which is, for example, is acquired, and not congenital, should be interpreted, in our view, in an extremely broad, not only physical but also, above all, socio-physical sense.

"Inability to ensure by himself or herself, wholly or partly, the necessities of a normal individual life" is sufficiently inherent in older disabled parents who, over their age and naturally impaired health, which, in turn, may objectively not meet strictly specific, limited, including international criteria for the concept of "disability", are unable to provide sufficient financial or other material support for themselves.

On the other hand, the incapacity of the elderly parents, their "inability to ensure by himself or herself, wholly or partly, the necessities of a normal individual life", on the contrary, is often not the consequence of their natural age, which causes the natural limitation of their health, but the consequences of their severe, both congenital and acquired within the scope of their work experience, physical and psychological injuries that cause their disability in a narrow, generally accepted sense of the term.

It should also be mentioned that within the framework of certain UN documents of a recommendation, declaratory, indicative, and other similar nature, there is a general, rather inaccurate or even sometimes contradictory definition of the term "disability". For example, paragraph 18 of the Standard Rules on the Equalization of Opportunities for Persons with Disabilities as of 20 December 1993 states the following (provided from the original source): "18. The term "handicap" means the loss or limitation of opportunities to take part in the life of the community on an equal level with others" (Standard Rules on the Equalization of Opportunities for Persons with Disabilities, 1993).

In our opinion, "the loss or limitation of opportunities to take part in the life of the community on an equal level with others" cannot but include or imply the complete incapability or substantially limited ability of disabled persons, in particular, older incapacitated parents, to carry out the necessary financial support for themselves, which implies, in turn, the natural 
reproduction of a socially important institution of the obligation of adult, legally capable, and able-bodied persons, including adult children, in accordance with the law, to provide financial or related support of the above socially-vulnerable, socially helpless persons.

The defined combined concept of a disabled person who is not only a disabled person in the abovementioned broader socio-physical contextual understanding, that is, a person who may have the characteristics of just an older incapacitated person, and at the same time, a person with a disability in a narrow, generally accepted and understandable term, and a retarded person, but also a person who in connection with the above lawfully uses fundamental social right to be on regular financial or other related support of other persons determined by the content of the relevant rules of national branch legislation, is given in paragraph (f) of Art. 3 "Definition" of the Convention on the International Recovery of Child Support and Other Forms of Family Maintenance as of 23 November 2007 (hereinafter referred to as the Convention on the International Recovery) (provided from the original source): "(f) "vulnerable person" means a person who, by reason of an impairment or insufficiency of his or her personal faculties, is not able to support him or herself" (Convention on the International Recovery of Child Support and Other Forms of Family Maintenance, 2007).

\section{Legal institutionalization \\ of obligation to maintain disabled persons}

Specific normative-institutional or, more precisely, normatively-personified, important components of a modern institute of obligation to carry out financial or other material maintenance of certain disabled persons, including aged disabled parents, as well as components of a potential or actual violation of the norms of this institute, are clearly reproduced by the presence of necessary definitions of "creditor" and "debtor" in paragraphs a) and b) of the Convention on the International Recovery (provided from the original source): "a) "creditor" means an individual to whom maintenance is owed or is alleged to be owed; b) "debtor" means an individual who owes or who is alleged to owe maintenance" (Convention on the International Recovery of Child Support and Other Forms of Family Maintenance, 2007).

It is important to note that the main, basic field of application of the Convention on the International Recovery is the necessary promotion of the recognition and proper fulfilment of obligations by certain persons who are in one country to provide for the financial maintenance namely of minors and one of the parties to an official marriage, who, in turn, are in the territory of another state. However, paragraph 3 of Art. 2 "Scope" also states the following (provided from the original source): "Any Contracting State may declare that it will extend the application of the whole or any part of the Convention to any maintenance obligation arising from a family relationship, parentage, marriage or affinity, including in particular obligations in respect of vulnerable persons" (Convention on the International Recovery of Child Support and Other Forms of Family Maintenance, 2007).

Thus, as we can see, the relatively obvious subjectobject goal of the Convention on the International Recovery to protect the aforementioned right of disabled persons, including disabled parents, is reproduced, first of all, through fundamental institutional and family factors of family and affinity relations, secondly, this goal is reproduced by the obvious actualization of the factor of physical and social vulnerability of such persons.

Under paragraph 1 of Art. 4 "Designation of Central Authorities" of the Convention on the International Recovery, a Contracting State designates its own Central Authority to discharge the duties/functions that are imposed by the Convention on such an authority. Among the numerous detailed general and specific functions of such central authorities of individual states-parties to the Convention on the International Recovery, in accordance with paragraphs 1 and 2 of Article 6 "Specific functions of Central Authorities", the key ones should be noted: 1) to receive and transmit to each other the applications of legality and necessity of collecting the maintenance payments and appropriate mutual processing of such applications; 2) to initiate or facilitate the institution of proceedings, either criminal or administrative, in respect of such applications; 3) to encourage amicable solutions with a view to obtaining voluntary payment of maintenance, where suitable by use of mediation, conciliation or similar processes; 4) to facilitate the ongoing enforcement of maintenance decisions, including any arrears; 5) to facilitate the collection and expeditious transfer of maintenance payments (Convention on the International Recovery of Child Support and Other Forms of Family Maintenance, 2007).

The extremely important paragraph 2 of Art. 34 of the Convention on the International Recovery also clearly sets out measures that are sufficiently effective, accessible, and widely tested in the world practice to enforce specific decisions under the provisions of this Convention, i.e. measures to enforce the collection of the necessary funds from the offender (provided from the original source): "a) wage withholding; b) garnishment from bank accounts and other sources; c) deductions from social security payments; d) lien on or forced sale of property; e) tax refund withholding; f) withholding or attachment of pension benefits; g) credit bureau reporting; h) denial, suspension or revocation of various licenses (for example, driving licenses); i) the use of mediation, conciliation or similar processes to bring about voluntary compliance" (Convention on the International Recovery of Child Support and Other Forms of Family Maintenance, 2007). 
However, as for the possibility of criminal liability, then returning to the content of paragraph 2 of Art. 6 "Specific functions of Central Authorities" of the Convention on the International Recovery, which accordingly provides for the initiation or promotion by the Central Authorities of the initiation of proceedings in respect of claims for evasion of maintenance, it is evident that the possibility of initiating criminal proceedings against offenders depends on what kind of liability for committing the offense is provided for by the content of the national law of a particular State-Party to the Convention on the International Recovery.

\section{Conclusions}

Therefore, relevant norms of the current international law, i.e. mandatory provisions of various sources of modern UN law, as well as provisions of international documents of the UN of purely declarative, advisory, orienting, moral and other purpose character, within a number of international universal and subjectoriented, specialized conventions, declarations, principles, standard rules, and action programs, clearly affirm and actualize the fundamental, universal socioeconomic right of any person to receive financial, socioeconomic security, a satisfactory standard of living and well-being.

This right, in turn, stipulates the legitimate social, extremely important right of a number of the above clearly defined categories of disabled, socially-vulnerable persons to be on regular financial or other similar material maintenance of other persons determined by the content of the relevant norms of national branch legislation.

In the context of this article, we have established a relatively clear substantive-spectral correlation between the concepts of such vulnerable, helpless social-group categories as "older persons", "persons with disabilities", and "mentally retarded persons", which causes the presence of a broad socio-physical contextual concept of a disabled person.

The rules of the current international law provide for a clear mechanism for the international recovery of funds for the benefit of certain socially-vulnerable persons, for example, disabled relatives and, in particular, incapacitated parents.

\section{References:}

Declaration on Social Progress and Development on December 11, 1969. Retrieved from: http://www.un.org/ru/ documents/decl_conv/declarations/socdev.shtml (accessed 22 May 2019).

Declaration on the Rights of Mentally Retarded Persons on December 20, 1971 Retrieved from: http://www.un.org/ru/documents/decl conv/declarations/retarded.shtml (accessed 10 May 2019).

Declaration on the Rights of Disabled Persons on December 9, 1975. Retrieved from: http://www.un.org/ru/ documents/decl_conv/declarations/disabled.shtml (accessed 05 May 2019).

Universal Declaration of Human Rights as of 10 December 1948. Retrieved from: http://zakon4.rada.gov.ua/ laws/show/995_015 (accessed 12 June 2019).

International Covenant on Economic, Social and Cultural Rights as of 16 December 1966. Retrieved from: http://zakon2.rada.gov.ua/laws/show/995_042 (accessed 04 June 2019).

Convention on the Rights of Persons with Disabilities on December 13, 2006. Retrieved from: http://zakon4.rada.gov.ua/laws/show/995_g71 (accessed 12 June 2019).

United Nations Principles for Older Persons on December 16, 1991. Retrieved from: http://www.un.org/ru/ documents/decl_conv/conventions/oldprinc.shtml.g71 (accessed 17 June 2019).

Standard Rules on the Equalization of Opportunities for Persons with Disabilities as of December 201993. Retrieved from: http://www.un.org/ru/documents/decl_conv/conventions/disabled_intro.shtml (accessed 25 May 2019).

Convention on the International Recovery of Child Support and Other Forms of Family Maintenance on November 23, 2007. Retrieved from: http://zakon5.rada.gov.ua/laws/show/995_112 (accessed 27 May 2019).

Szmukler, G., \& Bach, M. (2015). Mental health disabilities and human rights protections. Glob Ment Health (Camb), 2, 20.

Basson, Y. (2017). State obligations in international law related to the right to an adequate standard of living for persons with disabilities. Law democracy \& development, 21, 68-83.

Durieux See, J-F., \& McAdam, J. (2004). Non-refoulement through time: the case for a derogation clause to the Refugee Convention in mass influx emergencies. International Journal of Refugee Law, 164, 13. 